\title{
MICROBIOLOGICAL EVALUATION OF PRECOOKED GOAT "BUCHADA"
}

\author{
Roberto Germano Costa ${ }^{1}$; Neube Michel dos Santos ${ }^{2 *}$; Ariosvaldo Nunes de Medeiros ${ }^{3}$; \\ Rita de Cássia Ramos do Egypto Queiroga ${ }^{4}$; Marta Suely Madruga ${ }^{5}$
}

\begin{abstract}
${ }^{1}$ Departamento de Agropecuária, Centro de Formação de Tecnólogos, Universidade Federal da Paraíba, Bananeiras, PB, Brasil; ${ }^{2}$ Engenheiro de Alimentos, Programa de Doutorado Integrado em Zootecnia, Universidade Federal da Paraíba, Areia, PB, Brasil; ${ }^{3}$ Departamento de Zootecnia, Centro de Ciências Agrárias, Universidade Federal da Paraíba, Areia, PB, Brasil; ${ }^{4}$ Departamento de Nutrição, Centro de Ciências da Saúde, Universidade Federal da Paraíba, João Pessoa, PB, Brasil; ${ }^{5}$ Departamento de Tecnologia Química de Alimentos, Centro de Tecnologia, Universidade Federal da Paraíba, João Pessoa, PB, Brasil
\end{abstract}

Submitted: June 13, 2005; Returned to authors for corrections: November 10, 2005; Approved: March 26, 2006

\begin{abstract}
The objective of the present work was to evaluate the microbiological characteristics of the precooked goat "buchada", a typical dish in North East of Brazil, composed mainly by goat viscera such as heart, lungs, liver, spleen, intestines, stomach and blood. Samples of "buchada" produced at the different areas of the State of Paraíba, Brazil, presented a high number of aerobic mesophilic bacteria, with values ranging from 5.5 to 6.9 $\log _{10} \mathrm{CFU} / \mathrm{g}$. All samples presented total coliforms, and $96.6 \%$ presented fecal coliforms, with values between 2.3 and $5.0 \log _{10} \mathrm{NMP} / \mathrm{g}$. The occurrence of Staphylococcus aureus was observed in one sample only, at a proportion of $4.0 \log _{10} \mathrm{CFU} / \mathrm{g}$. Salmonella was absent in all samples. Water activity was around 0.98 and $\mathrm{pH}$ close to neutrality except for the samples collected in Campina Grande which presented $\mathrm{pH}$ 5.1, significantly lowar $(p<0.05)$ than the other products. Results indicate inadequate hygienic-sanitary practices during slaughter and processing, requiring preventive measures to minimize contamination at the critical points of the process and to guarantee products with longer shelf life and desirable quality standards.
\end{abstract}

Key word: organs, viscera, hygienic-sanitary conditions, "buchada"

\section{INTRODUCTION}

Goat breeding has grown as profitable activity for the Brazilian economy in the last years, especially in the Northeastern region due to the adaptability of goats to the semiarid climate and to lesser nutritional requirement they present. The meat of the animals is the most valuable product but by-products increase profitability of the process.

The demand for processed viscera has increased significantly in large Brazilian urban centers (4). However, society still presents a negative perception of the edible components not belonging to carcass of small ruminants, associating them to low-quality products. According to Zapata (22) goat products do not take part of the Brazilian population food habits especially due to their low quality as result of the large number of illegal slaughterhouses, lacking any sanitary surveillance.

The "buchada", a traditional Brazilian dish, represents an important economic alternative for utilization of edible components not belonging to carcass, which yield may exceed $20 \%$ in relation to the live weight and a budget equivalent to $50 \%$ of the total obtained with the carcass (8). Generally, the "buchada" is composed of heart, lungs, liver, spleen, intestines, stomach and blood, and these components must be rationally handled in order not to impair the consumers' health, once these components are vulnerable to microbial contamination (10).

The need to assure microbiological safety and food quality as well as longer shelf life has stimulated the performance of researches. Some microorganisms of interest in the evaluation of the precooked goatlike "buchada" are coliforms, indicative

*Corresponding Author. Mailing address: Rua Luis Alves da Rocha, 304/201, Bessa. 58037-380, João Pessoa, PB, Brasil. E-mail: rcqueiroga@uol.com.br 
of fecal contamination during slaughter/processing, also indicating the possible presence of pathogen microorganisms. Santos et al. (18) mentioned many authors and emphasized among pathogen microorganisms the Salmonella spp. as the second cause for food-induced bacterial diseases in the period from 1995 to 1998 in Latin America, only behind Staphylococcus sp., and that from the Salmonella vines isolated in the state of São Paulo in the period from 1985 to 1996, 34\% were originated from meat and by-products. Frazier and Westhoff (8) emphasized that spores produced by some bacteria present thermic resistance of up to 20 hours at $100^{\circ} \mathrm{C}$ for their complete destruction.

The determination of the microbial load of the commercialized precooked goatlike "buchada" along with the follow up of the processing stages will allow detecting the critical points of the productive process for solution in further stage, thus decreasing the incidence of deteriorating and pathogen microorganisms. These aspects would guarantee good physical-chemical and sensorial quality products with the maintenance of their original properties and the reduced risk of alimentary toxinfections and increased shelf life as result (6).

The objective of this work was to evaluate the microbiological quality of the precooked goatlike "buchada" based on the total counting of aerobic mesophilic bacteria, total and fecal coliforms, Staphylococcus aureus and Salmonella spp. determination as well as $\mathrm{pH}$ and water activity values.

\section{MATERIALS AND METHODS}

The experiment was conducted using precooked goatlike "buchada" produced in informal slaughterhouses in cities of Campina Grande, Remígio, Barra de Santa Rosa, São João do Cariri and Patos, including the Agreste, Borborema and Sertão regions in the state of Paraíba. Four sequenced collections were performed in a period of seven consecutive days and the samples were collected in the five cities previously mentioned, totalizing 20 samples. At the end of this process, the microbiological analyses were conducted in the following week, procedure adapted to the other samples.

All slaughter and processing stages of the product were followed, in other words, anesthetizing, bleeding, skinning, cleanness, thermic treatment of viscera and confection of the "buchada" without, however, interfering in the process methodology. The samples collection was performed shortly after the attainment of the final product.

For transportation, the samples were packed in transparent plastic sacks with hermetic seal previously sterilized with iodinated alcohol and registered in informative cards containing date and place of collection. The samples were transported in isothermal boxes with ice to the microbiology laboratory and frozen in freezer under average temperature of $-10^{\circ} \mathrm{C}$ for a period not longer than seven days. The microbiological analyses were conducted in the Food Quality Control Laboratory of the Technicians Formation Center - Paraíba Federal University.

\section{"Buchada" processing flowchart}

The "buchada" processes, performed in the stores selected generally follow the same slaughter and production flowchart (Fig. 1).

The slaughter process was composed of anesthetizing through the traditional method of losing consciousness with the use of a wooden stick, suspension of the animal through the back paws and bleeding through jugular vein incision, where blood was collected in recipient and left until complete coagulation. In the Campina Grande slaughterhouse, the blood was not collected. The skin and the limbs extremities were manually removed with the aid of knives.

Evisceration started with white organs; stomach and intestines with the removal of the gastrointestinal content and later washing. The guts were removed with the aid of a stick

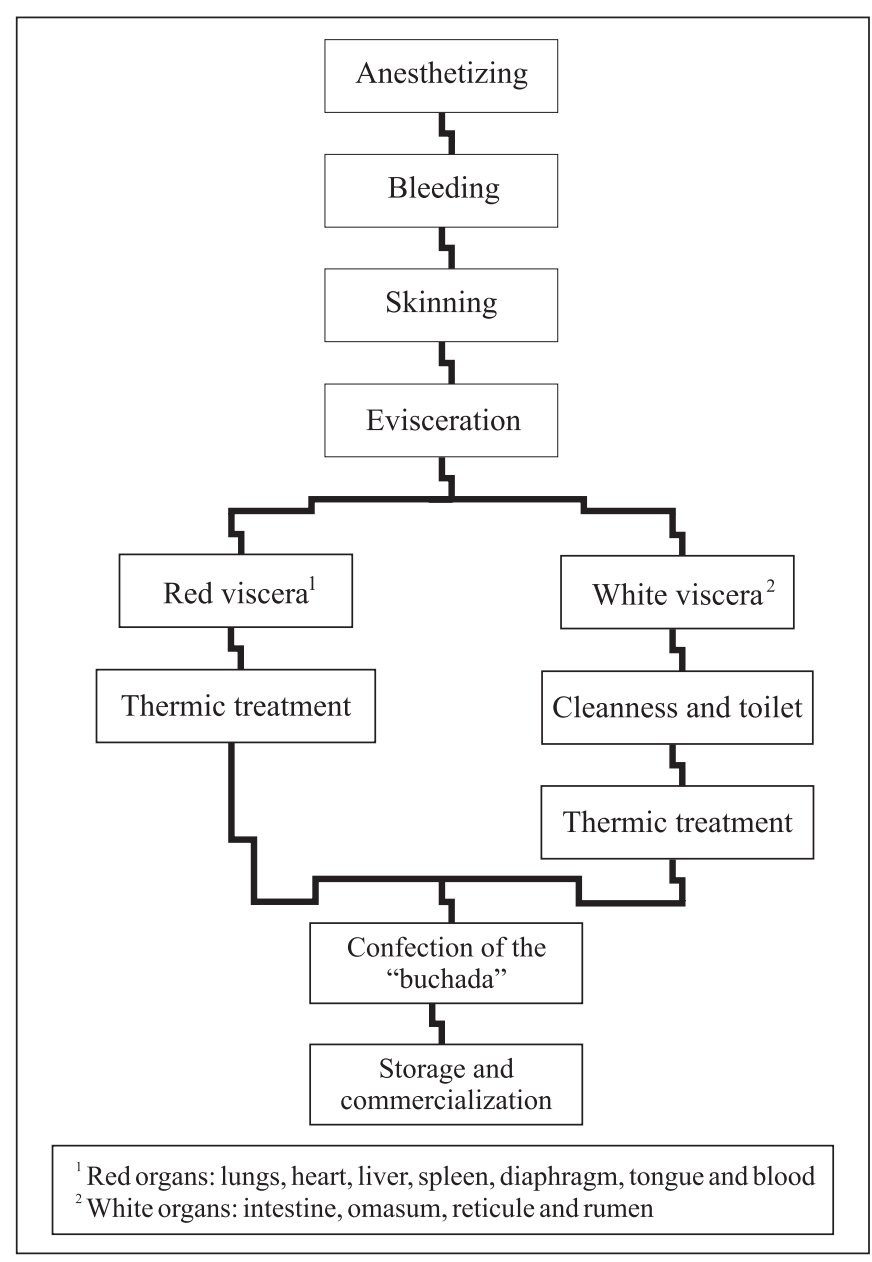

Figure 1. "Buchada" production stages flowchart. 
and in the case of the reticule-rumen, the interior mucosa was removed through immersion in water at $70^{\circ} \mathrm{C}$ for an average period 5 minutes. When the cleanness process finished, the thermic processing was performed, except for the reticule-rumen that were cut and sewed in form of sacks or bags for further filling with minced viscera (minced).

The red viscera initially removed from head, trachea and esophagus were scalded along with the coagulated blood for a period no longer than 30 minutes under water temperature ranging from 70 to $90^{\circ} \mathrm{C}$. The confection of the "buchada" consisted of cutting the red and white (minced) viscera and adding greenery and seasonings followed by the filling and closing of the "paunch", thus obtaining the final product.

\section{Microbiological analyses}

For the performance of the microbiological analyses, the samples were initially triturated in triturating equipment (Stomacher) for an average period of 5 minutes. Dilutions from $10^{-1}$ to $10^{-6}$ were performed and the inoculations were performed according to methodology proposed by Vanderzant and Splittstoesser (20) for the performance of the total counting of aerobic mesophilic bacteria, determination of the most probable number per gram of total and fecal coliforms, counting of Staphylococcus aureus and determination of Salmonella ssp.

Total counting of aerobic mesophilic bacteria - Using Plate Count Agar-PCA agar (BD), as culture medium, with inoculation by spread plate followed by incubation at $35^{\circ} \mathrm{C}$ during $48 \mathrm{~h}$. Results were expressed as CFU/g.

Total and fecal coliforms - The most probable number (MPN) of total coliforms was estimated by the 5-tube method using Lauryl Tryptose broth (Difco) incubated at $35 \pm 0.5^{\circ} \mathrm{C}$ and confirmed in brilliant Green Lactose bile broth (Difco) also at 35 $\pm 0.5^{\circ} \mathrm{C}$. The fecal coliforms counts were estimated after incubation at $44.5 \pm 0.2^{\circ} \mathrm{C}$ in EC medium (Difco).

Staphylococcus aureus - Samples were serially diluted in sterile $0.85 \%$ saline and aliquots of $0.1 \mathrm{~mL}$ were surface plated on Baird Parker agar (Oxoid) and incubated at $37^{\circ} \mathrm{C}$ for $24-48 \mathrm{~h}$. From each plate, five grey to black colonies, with or without halos, were selected and transferred to slants of Tryptic Soy Agar and incubated overnight at $37^{\circ} \mathrm{C}$.

Salmonella ssp. - Twenty-five g of sample were homogenized with $225 \mathrm{~mL}$ Lactose Broth (Difco) and incubated for $24 \mathrm{~h}$ at $35^{\circ} \mathrm{C}$. One $\mathrm{mL}$ of the lactose broth was also transferred to Kaufman's Tetrationate Broth (Merck) and incubated for $24 \mathrm{~h}$ at $35^{\circ} \mathrm{C}$. Was then streaked on Bismuth Sulpite Agar (Difco), XLD Agar and Hectoen Enteric Agar plates and incubated for $24 \mathrm{~h}$ at $35^{\circ} \mathrm{C}$. When suspect Salmonella colonies were present, they were transferred to TSI and LIA agar (Difco) slants and incubated for $24 \mathrm{~h}$ at $35^{\circ} \mathrm{C}$.

The $\mathrm{pH}$ determinations were conducted according to the AOAC (1). The water activity (Aw) was performed through direct method using hygrometer DECAGON DEVICES, label AQUA LAB, model CX2, according to manufacturer's instructions.

\section{Experimental design and statistical analysis}

The design used was fully random with five treatments and represented by the product acquired in each city (Campina Grande; Patos; Remígio; Barra de Santa Rosa; São João do Cariri). The four collections performed in each city were characterized as repetitions of the experiment.

The values obtained from the microbiological analyses corresponding to the counting of aerobic mesophilic bacteria, total and fecal coliforms and Staphylococcus aureus were transformed into base-10 logarithms for the performance of the statistical analysis. The averages were compared with the Tukey test at the significance level of $5 \%$ of probability using the PROC GML from the SAS program as software (19).

\section{RESULTS AND DISCUSSION}

Skinning and evisceration are considered as the main critical points during slaughter as result of the high microbial load present in skin, stomach and intestines (5). An average time between bleeding and evisceration of approximately 20 minutes was observed in stores visited.

The use of wooden boards, knives, plastic recipients and the handling of the product without previous hands and tools hygienics may be considered as critical points of the process. Rezer (16) verified the presence of a large number of aerobic mesophilic bacteria in goat viscera in natura as result of the lack of cleanness and disinfections of surfaces and equipments and the inadequate time and temperature conditions during food processing and conservation.

The lack of adequate tools such as pinafores, caps, masks and boots were also remarkable characteristics of the stores visited. Latre et al. (12) performed different microbiological analyses in order to evaluate the microbial load of meats and found the highest values of microorganisms counting in the surface of equipments in the evisceration sector, ranging from 4.0 to $6.0 \log _{10} \mathrm{CFU} / \mathrm{g}$.

The processes performed at Campina Grande and Barra de Santa Rosa presented times of viscera precooking below 20 minutes with temperatures not higher than $70^{\circ} \mathrm{C}$. In Patos, Remígio and São João do Cariri, a precooking time of 30 minutes was recorded at approximately $90^{\circ} \mathrm{C}$. Rezer (16) reported a reduction on the microbial load of goat viscera in natura of the order of $80 \%$ after thermic treatment with water at $90^{\circ} \mathrm{C}$ without previous time control.

In cities of Campina Grande, Remígio, São João do Cariri and Patos, the washing of viscera with citric acid and/or acetic acid was performed after thermic treatment. According to Vasconcelos et al. (21), the washing with acetic acid at $1 \%$ was effective in the $\mathrm{pH}$ reduction and in the significant reduction on the microbial load of sheeplike meat in natura without hindering the sensorial and nutritional quality of the product. Rezer (16) assured that the reduction on $\mathrm{pH}$ significantly decreases the 
microbial development, once the vast majority of pathogenic and deteriorating species multiply in $\mathrm{pH}$ values close to neutrality.

Among the edible components not belonging to carcass used in the confection of "buchadas", it was observed that the spleen is one of the components of the product present in all stores visited, except for the product acquired in Patos. The consumption of this organ is forbidden in Brazil, according to the article 260 of the Industrial and Sanitary Surveillance Regulation of Animal Origin Products (RIISPOA) (2), although it is commonly consumed in many countries due to its expressive nutritional value and high amino acids and iron contents (14).

Except for the "buchada" produced in Barra de Santa Rosa, the other products acquired in the region visited present large amounts of intestines in their composition, what may lead to a larger microbial counting in the final product, in case the cleanness and precooking stages are not properly performed. Rezer (16) evaluated the microbial load of goat intestines in natura commercialized in free markets and supermarkets and verified high concentrations of total and fecal coliforms, around $6.0 \log _{10} \mathrm{NMP} / \mathrm{g}$.

Due to the lack of microbiological standards for the precooked goatlike "buchada" in the Brazilian legislation, the general meat specifications were considered as parameter for the evaluation of the product.

It was verified that the "buchadas" analyzed, acquired in the five cities visited, presented high number of aerobic mesophilic bacteria, with values ranging from 5.5 to $6.9 \log _{10}$ $\mathrm{CFU} / \mathrm{g}$, indicating high contamination during the product's slaughter and processing stages (Table 1). Fung et al. (9) defined the range of 5.0 to $6.0 \log _{10} \mathrm{CFU} / \mathrm{g}$ as high aerobic microorganisms contamination, considering values up to 4.0 $\log _{10}$ CFU/g as acceptable. However, Jay (11) reported that a counting of total aerobic mesophilic bacteria between 5.0 and $7.0 \log _{10} \mathrm{CFU} / \mathrm{g}$ for raw meat are considered as normal and that for values above this range, one already observes the presence of unpleasant odors.

All samples presented total coliforms and $96.6 \%$ of them presented fecal coliforms between 2.3 and $5.0 \log _{10} \mathrm{NMP} / \mathrm{g}$, showing inadequate hygienic-sanitary conditions in the processing of the product (Table 1). Values above those detected in this study were found by Madruga et al. (13) in goat viscera in natura: heart, lungs, liver, stomach and intestines; with values for total and fecal coliforms ranging from 5.4 to $6.8 \log _{10} \mathrm{NMP} / \mathrm{g}$, respectively, indicating strong contamination during slaughter and/or processing stages.

In resolution $\mathrm{RDC} \mathrm{n}^{\circ} 12$ (3), there are no standards established for NMP/g of total and fecal coliforms for goatlike viscera and not specifically for "buchada" either; however, it only specifies that for poultry giblets, the maximum value allowed is of 5.0 $\log _{10} \mathrm{NMP} / \mathrm{g}$.

The occurrence of $S$. aureus was observed only in one sample from the city of Campina Grande at the proportion of $4.0 \log _{10}$ $\mathrm{CFU} / \mathrm{g}$. The presence of this type of microorganism is strongly related to precarious hygiene conditions. This pathogen is easily destroyed at temperatures close to $100^{\circ} \mathrm{C}$, however, it produces enterotoxins that cannot be eliminated even at temperatures above $100^{\circ} \mathrm{C}(17)$. Values above $6.0 \log _{10} \mathrm{CFU} / \mathrm{g}$ of this microorganism in food produce sufficient amounts of enterotoxins capable to cause gastroenteritis (15).

The result of the Salmonella spp. evaluation was absent in $25 \mathrm{~g}$ of product for all "buchada" samples evaluated. Madruga et al. (13) verified presence of Salmonella spp. in intestine samples, considering them inadequate to consumption.

The expressive water availability for the microbial development, verified by the high Aw values and $\mathrm{pH}$ close to neutrality found in "buchada" samples acquired in cities of Patos, Remígio, Barra de Santa Rosa e São João do Cariri demonstrated favorable conditions for microbial development, what characterizes the "buchada" as a product highly perishable (Table 2). Similar values were reported by Madruga et al. (13) for water activity and $\mathrm{pH}$ in goatlike viscera in natura.

The "buchada" acquired in Campina Grande presented low $\mathrm{pH}$, unlike the other products evaluated probably as result of the production of lactic acid originated from the beginning of the microbial deterioration process, once in the methodology applied, no viscera washing with citric acid or acetic acid was performed.

Table 1. Microbiological evaluation $\left(\log _{10}\right)$ of precooked goatlike "buchada" produced in the state of Paraíba.

\begin{tabular}{lcccccc}
\hline \multirow{2}{*}{ Microbiological Parameter $\left(\log _{10}\right)$} & \multicolumn{9}{c}{ City } & $\mathrm{CV}^{1}$ \\
\cline { 2 - 5 } & C.Grande & Patos & Remígio & B.S. Rosa & S.J.Cariri & \\
\hline aerobic mesophilic (CFU/g) & 6.1 & 6.5 & 6.9 & 5.7 & 5.5 & 12.34 \\
Total coliforms (NMP/g) & $5.0^{\mathrm{a}}$ & $3.7^{\text {ab }}$ & $3.6^{\mathrm{ab}}$ & $2.6^{\mathrm{b}}$ & $2.7^{\mathrm{ab}}$ & 29.53 \\
Fecal coliforms (NMP/g) & $5.0^{\mathrm{a}}$ & $3.7^{\mathrm{ab}}$ & $3.4^{\mathrm{ab}}$ & $2.6^{\mathrm{b}}$ & $2.3^{\mathrm{b}}$ & 28.59 \\
Staphylococcus aureus $(\mathrm{CFU} / \mathrm{g})$ & 4.0 & Absent & Absent & Absent & Absent & - \\
Salmonella ssp & Absent & Absent & Absent & Absent & Absent & - \\
\hline
\end{tabular}

Averages followed by different letters in line are different from each other by the Tukey test $(\mathrm{p}<0.05)$; ${ }^{1}$ Variation Coefficient. 
Table 2. Water activity (Aw) and $\mathrm{pH}$ of precooked goatlike "buchada" produced in the state of Paraíba.

\begin{tabular}{lcccccc}
\hline \multirow{2}{*}{ Parameter } & \multicolumn{5}{c}{ City } & \multirow{2}{*}{ CV $^{1}(\%)$} \\
\cline { 2 - 5 } & C. Grande & Patos & Remígio & B.S.Rosa & S.J.Cariri & \\
\hline Aw & 0.98 & 0.98 & 0.98 & 0.98 & 0.98 & 0.48 \\
pH & $5.1^{\mathrm{b}}$ & $6.3^{\mathrm{a}}$ & $6.5^{\mathrm{a}}$ & $6.7^{\mathrm{a}}$ & $6.5^{\mathrm{a}}$ & 7.67 \\
\hline
\end{tabular}

Averages followed by different letters in line are different from each other by the Tukey test $(\mathrm{p}<0.05)$; ${ }^{1}$ Variation Coefficient.

Pearson and Dutson (15) demonstrated that water activity values close to 0.96 are already sufficient to inhibit the growth of deteriorating bacteria; however, not sufficient to inhibit the development of deteriorating fungi and yeast, capable to multiply in Aw as low as 0.88 .

\section{CONCLUSIONS}

The "buchada" samples analyzed presented high values for aerobic mesophilic bacteria and total and fecal coliforms counting, suggesting inadequate hygienic-sanitary conditions in slaughter and processing stages, where the adoption of preventive measurements are required with the objective of minimizing contamination in critical points of the process in order to provide longer shelf-life and improved microbiological quality.

One verifies the need of a legislation with specific standards for the counting of aerobic microorganisms, total coliforms, fecal coliforms and Staphylococcus for the edible components not belonging to carcass and specially for the "buchada", due to the cultural and economical role it plays, especially in the Brazilian Northeastern region.

The high Aw values and $\mathrm{pH}$ close to neutrality demonstrated favorable conditions for microbial development, what characterizes the "buchada" as a highly perishable product.

\section{RESUMO}

\section{Avaliação microbiológica da "buchada” caprina pré-cozida}

Objetivou-se com o trabalho avaliar as características microbiológicas da "buchada" caprina pré-cozida, produto típico da culinária nordestina no Brasil, normalmente composta por vísceras, como coração, pulmões, fígado, baço, intestinos, estômago e sangue. As amostras de "buchada" produzidas em diferentes mesorregiões do estado da Paraíba apresentaram elevado número de bactérias mesófilas aeróbias, com valores variando de 5,5 a $6,9 \log _{10} \mathrm{UFC} / \mathrm{g}$. Todas as amostras apresentaram coliformes totais, das quais $96,6 \%$ continham coliformes fecais, entre 2,3 e 5,0 $\log _{10} \mathrm{NMP} / \mathrm{g}$. A ocorrência de Staphylococcus aureus foi observada apenas em uma amostra proveniente do município de Campina Grande, na proporção de $4,0 \log _{10} \mathrm{UFC} / \mathrm{g}$. Salmonella foi ausente para todas as amostras avaliadas. A atividade de água obtida foi em torno de 0,98 , com valores de $\mathrm{pH}$ próximos da neutralidade, exceto nas amostras adquiridas em Campina Grande que apresentaram $\mathrm{pH}$ em torno de 5,1, diferente $(\mathrm{p}<0,05)$ dos demais produtos. Conclui-se com os resultados, condições higiênico-sanitárias inadequadas nas etapas de abate e confecção da "buchada", fazendo-se necessário adotar medidas preventivas, com o intuito de minimizar a contaminação nos pontos críticos do processo e garantir produtos com maior tempo de vida útil e um padrão de qualidade desejável.

Palavras-chave: órgãos, vísceras, condições higiênico-sanitárias, "buchada"

\section{REFERENCES}

1. Association of Analytic Chemist - AOAC. Official Methods of Analysis. $19^{\text {th }}$ ed. Ass. Off. Analytical. Chem., Washington, D.C., 2000, 1219p.

2. Brasil. Decreto ${ }^{\circ} 2.244$ de 04/06/1997. Aprova o novo Regulamento de Inspeção Industrial e Sanitária de Produtos de Origem Animal (RIISPOA). Diário Oficial [da] República Federativa do Brasil. Brasília, DF, 04 jun. 1997.

3. Brasil. Ministério da Saúde-RDC-n ${ }^{\circ}$ 12. Regulamento técnico sobre padrões microbiológicos para alimentos, Diário Oficial [da] Republica Federativa do Brasil. Brasília, DF, 2 jan. 2001.

4. Carvalho, R.B. Potencialidades dos mercados para os produtos derivados de caprinos e ovinos. http://www.capritec.com.br, 2003.

5. Chandran, S.K.; Savell, J.W.; Griffin, D.B.; Vanderzant, C. Effect of slaughter-dressing fabrication and storage conditions on the microbiological and sensory characteristics of vaccum-packaged beef steaks. J. Food Sci., 51, 37-39, 1986.

6. Costa, R.G.; Madruga, M.S.; Santos, N.M.; Medeiros, A.N. Qualidade físico-química, química e microbiológica da "buchada" caprina. Higiene Alimentar, 19(130), 2005.

7. Costa, R.G.; Medeiros, A.N.; Madruga, M.S.; Cruz, S.E.S.B.S.; Melo, L.S. Rendimento de vísceras para "buchada" em caprinos Saanen alimentados com diferentes níveis de volumoso e concentrado. $2^{\circ}$ SINCORTE, João Pessoa, 2003, p.651.

8. Frazier, W.C.; Westhoff, D.C. Microbiologia de los Alimentos. Acribia, Zaragoza, 1993, 681p.

9. Fung, D.Y.C.; Kastner, C.L.; Hunt, M.C.; Dikeman, M.E.; Kropk, D. Mesophilic and psychrotrophyc bacteria population on hot-boned and conventionally processed beef. J. Food Prot., 43(7), 547-550, 1980. 
10. Gill, C.O. Microbiology of edible meat by-product. In: Pearson, A.M.; Dutson, T.R. Edible Meat By-product. London, Elsevier, 1988, p.47-82.

11. Jay, J.M. Microorganism in fresh ground meats: the relative safety of products with low versus high numbers. Meat Sci., 43, 59-66, 1996.

12. Vela, I.; Ortiz C.L.; Rodríguez, A.A.; Latre, M.V.; Cubero, G. Puntos críticos a considerar como fuentes de contaminación bacteriológica de canales en mataderos. Alimentaria, 35(282), 33-36, 1997.

13. Madruga, M.S.; Rezer, J.S.; Melo, H.M.G.; Pedrosa, N.A. Caracterização química e microbiológica de vísceras caprinas destinadas ao preparo de "buchada" e picado. $R$. Nacional da Carne, 27, (316), 37-45, 2003.

14. Pardi, M.C.; Santos, I.F.S.; Souza, E.R. Ciência Higiene e Tecnologia da Carne. Editora UFG, Goiânia, 1996, 1110p

15. Pearson, A.M.; Duston, T.R. Advances in Meat Research. AVI, Connecticut, 1986, 436p.

16. Rezer, J.S. Avaliação microbiológica e estudos de conservação térmica de vísceras caprinas. João Pessoa-PB, 2002, 103p.
(Dissertação de Mestrado em Ciência e Tecnologia de Alimentos. UFPB).

17. Roitmam, T.A.; Travassos, L.R.; Azevedo, J.L. Tratado de Microbiologia. Manole, São Paulo, 1988, 186p.

18. Santos, A.F.; Vizeu, D.M.; Destro, M.T.; Franco, B.D.G.M.; Landgraf, M. Determination of gamma radiation doses to reduce Salmonella spp in chiken meat. Ciênc. Tecnol. Aliment., 23(2), 200-205, 2003.

19. SAS Institute. Statistic Analyses Systems. Cary, Version 6.0, 1996 $300 \mathrm{p}$.

20. Vanderzant, C.; Splittstoesser, D.F. Compendium of Methods for the Microbiological Examination of Foods. APHA, Washington, 1992, $1219 \mathrm{p}$.

21. Vasconcelos, E.C.; Zapata, J.F.F.; Figueiredo, E.A.; Branco, M.A.A.C.; Borges, A.S. A microbiota da carcaça e da carne ovina tratada com ácido acético, embalada a vácuo e maturada por 48 dias. Ciênc. Tecnol. Aliment., 22(3), 2002.

22. Zapata, J.F.F. Tecnologia e comercialização de carne ovina. Semana da Caprinocultura Tropical Brasileira, Sobral, 1994, p.115-128. 